\title{
ISOLATION, IDENTIFICATION AND TECHNOLOGICAL PROPERTIES OF LACTIC ACID BACTERIA FROM RAW COW MILK
}

\author{
ISOLAMENTO, IDENTIFICAÇÃO E PROPRIEDADES TECNOLÓGICAS DE \\ BACTÉRIAS ÁCIDO LÁCTICAS A PARTIR DE LEITE DE VACA CRU
}

\author{
Asuman KARAKAS-SEN ${ }^{1}$; Emin KARAKAS ${ }^{2}$ \\ 1. Department of Food Technology, Yenisehir Vocational School, University of Uludag, Yenisehir, Bursa 16900, Turkey; 2. Department \\ of Laboratory and Veterinary Health, Yenisehir Vocational School, University of Uludag, Yenisehir, Bursa 16900, Turkey. \\ akarakas@uludag.edu.tr
}

\begin{abstract}
Lactic acid bacteria are used as starter culture for the production of fermented dairy products, and that occur naturally as indigenous microbiota of the raw milk. In this study, lactic acid bacteria were isolated from raw cow milk samples. The serial dilutions of raw milk were made and plated onto LM17 agar and MRS agar adjusted to pH 5.4. The isolates were firstly identified based on cell morphology, reaction to gram stain, catalase production, growth in MRS broth containing $2 \%, 4 \%$, and $6.5 \% \mathrm{NaCl}$, growth ability of different temperatures and formation of gas in MRS broth. Acid formation in 10\% reconstituted skim milk and antimicrobial activity against foodborne pathogens Listeria monocytogenes ATCC 7644, Stapylococcus aureus ATCC 25923, and Clostridium perfringens ATCC 13124 were examined using agar well diffusion method. The total of $90 \mathrm{LAB}$ isolates were classified as Lactobacillus (37.78\%), Lactococcus (36.67\%), Enterococcus (20.00\%), Streptococcus (4.44\%), and Leuconostoc (1.11\%). Based on technological properties, 56 of 90 isolates ( 42 cocci, 14 rods) were selected, and further identified at the species level using API 20 Strep and API $50 \mathrm{CH}$ identification system, respectively. The Lactobacillus isolates were identified as Lactobacillus acidophilus, Lactobacillus fermentum, Lactobacillus paracasei ssp. paracasei, Lactobacillus plantarum, Lactobacillus delbrueckii ssp. lactis, and Lactobacillus rhamnosus. The enzymatic profiles of the 17 selected isolates were studied with API ZYM system. The Lactobacillus spp. strains tested displayed high leucine arylamidase activity. Two Lactococcus lactis ssp. lactis AKS320.1 and AKS320.2 strains and one Enterococcus faecalis AKS424 strain were able to produce bacteriocin. In conclusion, some of these isolates could be considered as potential starter culture candidates for fermented milk products.
\end{abstract}

KEYWORDS: Lactic acid bacteria. Bacteriocin. Isolation. Identification. Raw cow milk.

\section{INTRODUCTION}

Lactic acid bacteria (LAB) are an industrially important group of bacteria and used as starter cultures for the production of fermented milk products (e.g. yoghurt and some cheeses) in the dairy industry. LAB are gram positive, nonsporeforming, catalase negative bacteria, and contain the following genera: Aerococcus, Alloicoccus, Carnobacterium, Enterococcus, Lactobacillus, Lactococcus, Leuconostoc, Oenococcus, Pediococcus, Streptococcus, Symbiobacterium, Tetragenococcus, Vagococcus and Weissella (HORVATH et al., 2009). These groups of bacteria have been isolated from the raw materials of food, such as raw milk (CORROLER et al., 1998; RODRIGUEZ et al., 2000; TULINI et al., 2016; ASPRI et al., 2017; PERIN et al., 2017), plants (ALEMAYEHU et al., 2014), meat (EGAN, 1983), vegetables (KELLY et al., 1998), and fruits (CHEN et al., 2017).

Natural habitats, including the indigenous flora of raw milk, can be good source of novel LAB strains with the potential desirable properties for use in the production of novel fermented dairy products (CORROLER et al., 1998; RODRIGUEZ et al., 2000; WOUTERS et al., 2002; DELAVENNE et al., 2012; TULINI et al., 2016; PERIN; NERO, 2014). The most frequently isolated LAB genera from raw milk and dairy products that were made from raw milk were Enteroccoccus, Lactococcus, Lactobacillus, Leuconostoc, and Streptococcus (PERRY; SHARPE, 1960; FRANCIOSI et al., 2009). In another study, lactococcal strains were isolated from raw milk in Camembert cheese area and identified by using both phenotypic criteria (physiological and biochemical tests) and genotypic (RAPD) criteria. The raw milk microflora is also important for the ripening of the cheese (CORROLER et al., 1998). The population of nonstarter lactic acid bacteria (NSLAB) in Cheddar cheese produced by commercial manufacturers in the United Kingdom were identified using commercially available identification system (API $50 \mathrm{CH}$ system). Lactobacillus paracasei ssp. paracasei and Lactobacillus plantarum were the most frequently isolated species (WILLIAMS; BANKS, 1997). The major sources of bacteria in 
raw milk are from within the udder, the exterior of the teats and the udder, the milking machine, the storage equipments, the housing, bedding, feed, air and water (QUIGLEY et al., 2013).

The important metabolic activities of LAB used in the manufacture of fermented milk products are mainly the production of lactic acid from milk sugar lactose and other sugars, aroma compounds, and exopolysaccharides. Moreover, LAB produce several substances with the antimicrobial activity: organic acids (lactic acid, acetic acid etc.), hydrogen peroxide, diacetyl, acetaldehyde and bacteriocins (DEEGAN et al., 2006; MAYO et al., 2010; KARAKAS-SEN; AKYOL, 2012). The proteolytic activity of the dairy starter cultures is important for their growth in milk, the formation of flavour in dairy products, and the maturation of cheese (LAW; KOLSTAD, 1983; TULINI et al., 2016).

The collections of dairy relevant microorganisms originating from raw milk environment contain strains with the potential features for the novel dairy product development (WOUTERS et al., 2002). Therefore, the wild-type lactococci isolated from raw milk samples are a potential source of new strains with desired properties. Moreover, the artisanal, starter-free, traditional cheeses made with raw milk ripen faster and develop more intense flavour than cheeses made with pasteurized or microfiltered milk (CORROLER et al., 1998). In another study, wild lactococci strains isolated from raw milk, fermented milk and from non-dairy origin generally produced specific flavour different from those produced by industrial strains (AYAD et al., 1999).

Bacteriocins, ribosomally synthesized antimicrobial peptides produced by various bacteria, display antimicrobial activity against closely related bacterial strains, and are widely used as food preservative in food industry, in agriculture and veterinary medicine as a therapeutic (KARAKASSEN et al., 1999; DEEGAN et al., 2006). These peptides are sensitive to specific proteolytic enzymes and can be heat stable. Bacteriocin production ability was widespread among LAB isolated from raw milk (RODRIGUEZ et al., 2000; ASPRI et al., 2017). The strains producing bacteriocin nisin were most abundant among LAB isolated from raw cow, ewes and goat milks. Furthermore, lactococci producing lacticin 481 and enterococci producing enterocin AS-48 have also been found at high incidence (RODRIGUEZ et al., 2000). Lactococcus lactis strain producing bacteriocin nisin $\mathrm{Z}$ was isolated from a traditional fermented Nigerian dairy product, wara that made from raw cow milk (OLASUPA et al., 1999).
Recently, ASPRI et al. (2017) reported the isolation of enterocin producing E. faecium strains from raw donkey milk.

It is important to have wild $\mathrm{LAB}$ isolates from the raw food materials and the fermented foods possibility to use these isolates as starter cultures in the production of fermented foods. Comparative analysis of LAB genomic data obtained by using next generation sequencing techniques showed a remarkable diversity in $\mathrm{LAB}$ group at numerous taxonomic levels, i.e. order, family, group, genus and even species (DOUILLARD; de VOS, 2014).

The objective of this study was to isolate the natural lactic acid bacteria from raw cow milk, identify, characterise and determine some technologically important properties of these natural LAB isolates in order to use as starter culture for the production of fermented milk products. The results show that raw cow milk is a good source of industrially important LAB.

\section{MATERIAL AND METHODS}

\section{Isolation of lactic acid bacteria from raw cow milk}

Strains of LAB were isolated from raw cow milk samples. A total of 11 raw cow milk samples were aseptically taken into the sterile bottles from bulk tanks at different dairy farms located in Bursa, Turkey. All raw milk samples were kept at $4^{\circ} \mathrm{C}$ during transport to the laboratory. Serial dilutions of the milk samples were immediately made in $1 / 4$ Ringers solution (Oxoid), and were spread onto MRS agar (Difco) pH adjusted to 5.4 with acetic acid to facilitate the isolation of the genus Lactobacillus, and M17 agar (Difco) supplemented with \% 0.5 lactose (LM17) to isolate other LAB (DUNCAN et al., 2004). In order to inhibit the growth of yeast and molds, natamax ${ }^{\mathrm{TM}}$ (Danisco) was used at $200 \mathrm{mg} \mathrm{l}^{-1}$ concentration in the isolation plates. The plates were incubated for $48 \mathrm{~h}$ at $30^{\circ} \mathrm{C}$ and $45^{\circ} \mathrm{C}$ aerobic or under anaerobic conditions in an anaerobic jar (HP0011A, Oxoid) with anaerobic generation kit (BR38, Oxoid). After incubation, the individual colonies having a different morphology were picked and streaked on LM17 or MRS agar plates. Once the isolates were purified, phenotypic and other tests were carried out. The isolates were stored as frozen stocks at $-20^{\circ} \mathrm{C}$ in MRS broth containing $20 \%$ (v/v) glycerol.

\section{Characterisation and identification of lactic acid bacteria isolates to genus level}

Gram positive and catalase negative colonies were considered as members of lactic acid 
bacteria and further studied. These isolates were firstly identified to the genus level by performing the following tests: cell morphology, growth for $7 \mathrm{~d}$ at $10^{\circ} \mathrm{C}$ (for cocci), for $7 \mathrm{~d}$ at $15^{\circ} \mathrm{C}$ (for rods) in a cooling incubator (JSR, Korea), and growth at $45^{\circ} \mathrm{C}$, ability to grow in MRS or M17 broth with $2 \%, 4 \%$ and $6.5 \% \mathrm{NaCl}$ concentrations for $96 \mathrm{~h}$, carbon dioxide production from glucose by subculturing the isolates in MRS broth with inverted Durham tubes (COGAN et al., 1997; HARRIGAN, 1998). After 48 $\mathrm{h}$ incubation at $37^{\circ} \mathrm{C}$, broth media were examined for growth, and the results were recorded. The isolates were also tested for motility in MRS agar in a test tube. Endospor staining was performed by Schaeffer-Fulton's method (SCHAEFFER; FULTON, 1933). Oxidase test was done with the test sticks (Merck, Millipore). The production of ammonia from arginine was tested with the method of HARRIGAN (1998). The ability of an isolate to produce acetoin (acetylmethylcarbinol) and diacetyl was checked by the application of the VogesProskauer test (Barritt's modification) (HARRIGAN, 1998).

\section{Characterisation and identification of lactic acid bacteria isolates to species level}

The isolates identified as the genera of lactic acid bacteria were further characterised at the species level by the use of API 20 Strep or API 50 $\mathrm{CH}$ carbohydrate fermentation strips (bioMérieux, France). The identity of the selected 42 lactococci, enterococci or streptococci, and 14 lactobacilli isolates was further assessed by the use of API 20 Strep kit (20600, bioMérieux) and API 50 CH kit using API 50 CHL media (50300, bioMérieux) according to manufacturer's instructions, respectively. The identification of the isolates was obtained using the apiweb ${ }^{\mathrm{TM}}$ software (bioMérieux, France).

\section{Acid production ability}

Acid production ability was determined in sterile (for $30 \mathrm{~m}$ at $110^{\circ} \mathrm{C}$ ) $10 \%$ reconstituted skim milk (Oxoid, UK). A 1\% inoculum from an overnight MRS culture was used to inoculate the milk. The cultures were incubated for $24 \mathrm{~h}$ at $37^{\circ} \mathrm{C}$ and their $\mathrm{pH}$ were measured using a $\mathrm{pH}$ meter $(\mathrm{pH}$ 3210, WTW, Weilheim, Germany). The characteristics of the coagulum (curd firmness, curd breaking, whey amount, presence of gas bubbles) were also recorded by visual inspection (HARRIGAN, 1998).

\section{Proteolytic activity and starch hydrolysis}

Proteolytic activity was determined by streaking each strain onto a Milk agar plate which was prepared by addition of $10 \%$ reconstituted skim milk to Nutrient agar (Merck, Millipore). Inoculated plates were incubated for $18 \mathrm{~h}$ at $37^{\circ} \mathrm{C}$. The clear or strong opaque zone around the growth were evaluated as positive for the protease activity (HARRIGAN, 1998).

Starch hydrolysis was tested using Starch agar (Merck, Millipore). After overnight incubation, the plates were flooded with $5-10 \mathrm{ml}$ iodine solution, and inspected the clear zone for amylase activity (HARRIGAN, 1998).

\section{The antimicrobial activity of LAB isolates against foodborne pathogens}

The antimicrobial activities of LAB isolates were tested by agar well-diffusion method (KARAKAS-SEN et al., 1999) using Listeria monocytogenes ATCC 7644, Stapylococcus aureus ATCC 25923, and Clostridium perfringens ATCC 13124 as the indicator strain. For some isolates, the indicator strains Escherichia coli EC100, MC1022, Lb. bulgaricus 572, which was isolated from Y572 yoghurt culture (Danisco), and the isolate $L b$. fermentum AKS222.2 were also used.

The indicator strains were grown in Tryptic Soy Broth (TSB) supplemented with $0.3 \%$ yeast extract (TSBYE) at $37^{\circ} \mathrm{C}$, otherwise stated. $C$. perfringens was incubated anaerobically in an anaerobic jar. Molten soft TSAYE agar (0.7\% agar) at $45^{\circ} \mathrm{C}$ was seeded with the fresh overnight culture of the indicator strain. Lb. bulgaricus 572 and $L b$. fermentum AKS222.2 were grown in MRS broth and MRS agar. The wells in agar were made with a sterile cork borer. In order to test antimicrobial activity, the isolated LAB strains were grown for 18 $\mathrm{h}$ at $37^{\circ} \mathrm{C}$ in MRS broth (Difco). After incubation, the cultures were centrifuged at $10000 \mathrm{~g}$ for $15 \mathrm{~m}$. The resulting supernatants were adjusted to $\mathrm{pH} 7.0$ with $1 \mathrm{~N} \mathrm{NaOH}$ and passed through a filter $(0.22$ $\mu \mathrm{m})$. The cell free supernatants $(75-150 \mu \mathrm{l})$ were transferred into the wells. After keeping the agar plate at $4^{\circ} \mathrm{C}$ to allow diffusing into agar, the plates were incubated at $37^{\circ} \mathrm{C}$ until the growth of the indicator strains. The agar plates seeded with the indicator strain $C$. perfringens were incubated in anaerobic jar. The plates were subsequently examined for zone of inhibition.

The cell free supernatants of three isolates (Lc. lactis ssp. lactis AKS320.1, AKS320.2, and E. faecalis AKS424) were tested for sensitivity to $\alpha$ amylase, catalase, lipase, proteinase $\mathrm{K}$, pepsin, $\alpha-$ chymotrypsin, trypsin, and papain enzymes (Sigma) 
at the concentration of $10 \mathrm{mg} / \mathrm{mL}$ using the method of RYAN et al. (1996). The supernatants were incubated with the enzymes for $2 \mathrm{~h}$ at $37^{\circ} \mathrm{C}$. Following incubation, the level of antimicrobial activity retained was evaluated via the agar well diffusion method using L. monocytogenes ATCC 7644 as the indicator strain. Enzyme solutions were also applied into a well adjacent to wells containing the supernatants made on TSAYE agar plates seeded with the indicator strain. Protease sensitivity was observed as a half moon shaped zone of inhibition.

\section{Enzyme activity}

Enzyme activities of the selected 17 strains representing each strain of $\mathrm{LAB}$ isolates, were measured using the commercial, semiquantitative API ZYM system (bioMérieux) following the manufacturer's recommendations. Briefly, the sixtyfive microliters of cell suspension equal to No:5 McFarland standard was transferred into each well of the API ZYM strips. The test strips were incubated for $4 \mathrm{~h}$ at $37^{\circ} \mathrm{C}$ in a humid atmosphere, and developed by adding 1 drop of developing reagents ZYM A (Tris-hydroxymethylaminomethane $25 \mathrm{~g}$; hydrochloric acid (37\%) $11 \mathrm{ml}$; sodium lauryl sulphate $10 \mathrm{~g}$; distilled water to 100 $\mathrm{ml}$ ) and ZYM B (Fast blue BB $0.12 \mathrm{~g}$; methanol 40 $\mathrm{ml}$; dimethylsulfoxide (DMSO) $60 \mathrm{ml}$ ) to each of the wells. Colour development, indicating positive reactions, was graded with the reference to the API ZYM colour chart.

\section{RESULTS AND DISCUSSION}

\section{Isolation and identification of lactic acid bacteria from raw cow milk}

Lactic acid bacteria are mostly used as starter culture for the production of fermented dairy products, and that occur naturally as indigenous microbiota of the raw milk (ASPRI et al., 2017; PERIN et al., 2014). Therefore, the raw milk is considered as a good source for the isolation of LAB with technological potential (TULINI et al., 2016).

In this study, the raw cow milk samples were collected from the 11 different dairy farms located in Bursa, Turkey in order to isolate lactic acid bacteria. Gram-positive, catalase-negative, oxidase-negative and non-spore forming isolates were evaluated as lactic acid bacteria. $90 \mathrm{LAB}$ were isolated from raw cow samples, and were identified as Lactococcus (36.67\%), Enterococcus $(20.00 \%)$, Streptococcus (4.44\%), Leuconostoc (1.11\%), and Lactobacillus $(37.78 \%)$ based on physiological and biochemical characterization.

Table 1. Isolated wild lactic acid bacteria from raw cow milk identified at species level by API 20 Strep (for cocci), or API $50 \mathrm{CH}$ (for rods) system

\begin{tabular}{lcccc}
\hline Species identified & $\begin{array}{l}\text { Number of } \\
\text { isolates }\end{array}$ & $\boldsymbol{\%}^{\mathbf{a}}$ & $\boldsymbol{\%}^{\mathbf{b}}$ & $\boldsymbol{\%}^{\mathbf{c}}$ \\
\hline Cocci & & & & \\
Lactococcus lactis ssp. lactis & 29 & 69.05 & & 51.79 \\
Enterococcus durans & 5 & 11.91 & & 8.93 \\
Enterococcus faecalis & 3 & 7.14 & & 5.35 \\
Enterococcus faecium & 3 & 7.14 & & 1.79 \\
Enterococcus avium & 1 & 2.38 & & 1.79 \\
Streptococcus salivarius & 1 & 2.38 & & 75.00 \\
Total (Cocci) & 42 & 100 & & \\
& & & & \\
Rods & 1 & & 7.14 & 1.79 \\
Lactobacillus acidophilus & 1 & & 14.79 & 8.93 \\
Lactobacillus fermentum & 5 & & 21.43 & 5.37 \\
Lactobacillus paracasei ssp. paracasei & 2 & & 14.29 & 3.57 \\
Lactobacillus plantarum & 3 & & & 25.00 \\
Lactobacillus delbrueckii ssp. lactis & 2 & & 100 & 100 \\
Lactobacillus rhamnosus & 14 & & & \\
Total (Rods) & & & & \\
General Total & 56 & & & \\
\hline
\end{tabular}

${ }^{a}$ Percentage of strains over the total of coccal shape strains. ${ }^{b}$ Percentage of strains over the total of rod shape strains. ${ }^{c}$ Percentage of strains over the total of isolated strains. 
In general, the members of Lactococcus genus are able to grow a medium containing $4 \%$ $\mathrm{NaCl}$, but not a medium containing $6.5 \% \mathrm{NaCl}$, and at $45^{\circ} \mathrm{C}$ (COGAN et al., 1997). Our results revealed that some of wild-type Lc. lactis ssp. lactis strains grew weakly in MRS broth containing $6.5 \% \mathrm{NaCl}$. This is an agreement with the results of previous studies reporting that Lc. lactis ssp. lactis strains were isolated from plants (NOMURA et al., 2006; ALEMAYEHU et al., 2014). The ability of the wild lactococci strains to grow in the presence of $6.5 \%$ $\mathrm{NaCl}$ could be functional for the production of some cheeses, which contain relatively high salt concentrations.

Based on their technological profile, 56 LAB (Table 1) were selected, and further identified at strain level using the API commercial system (API 20 Strep or API $50 \mathrm{CH}$ ) (Figure 1). The identified coccal shape strains were Lc. lactis ssp. lactis, E. durans, E. faecium, E. faecalis, E. avium, and S. salivarius (Table 1; Table 2). Our results revealed that the most dominant $\mathrm{LAB}$ strain was $L c$. lactis ssp. lactis $(51.79 \%)$ and the most dominant Lactobacillus strain was identified as Lactobacillus paracasei ssp. paracasei (8.93\%). All coccoid shape strains tested, except Streptococcus salivarius
AKS301.1, fermented ribose. None of the strain fermented inulin. Only few strains tested fermented sorbitol. These LAB isolates were three E. faecalis strains (AKS313.1, AKS419, and AKS424), E. faecium AKS350, and E. avium AKS365. The identified Lactobacillus strains were $L b$. acidophilus, Lb. fermentum, Lb. paracasei ssp. paracasei, Lb. plantarum, Lb. delbrueckii ssp. lactis, and Lb. rhamnosus (Table 1; Table 3). In the present study, only three isolates were belonged to heterofermentative group of Lactobacillus spp., and one of them was identified as Lb. fermentum AKS222.2 (Table 3). This is an agreement with the results of FRANCIOSI et al. (2009) reporting that $\mathrm{LAB}$ were isolated from raw cow milk in Italy. In another study, few lactobacilli were isolated from milk samples, and identified as $L b$. plantarum, $L b$. casei, Lb. brevis, and Lb. fermenti (PERRY; SHARPE, 1960). DELAVENNE et al. (2012) reported that the raw milk samples from cow, ewe and goat over one-year period, whatever their origin were dominated by Gram-positive catalase-negative cocci (presumptive lactococci and Leuconostoc), whereas enterococci and lactobacilli were present in significantly lower concentrations. a)
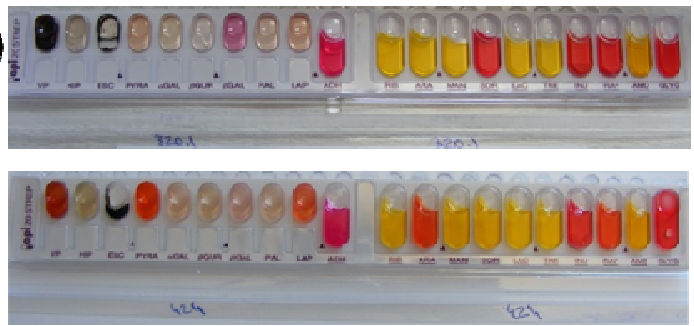

c)

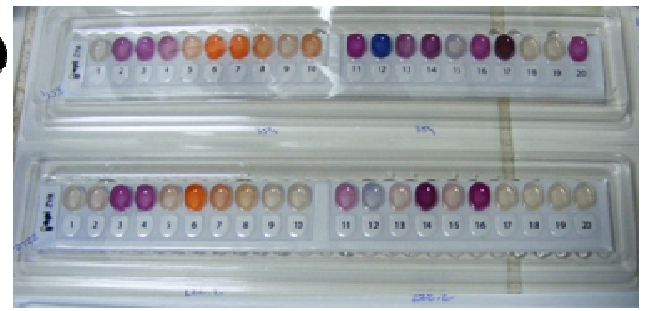

b)

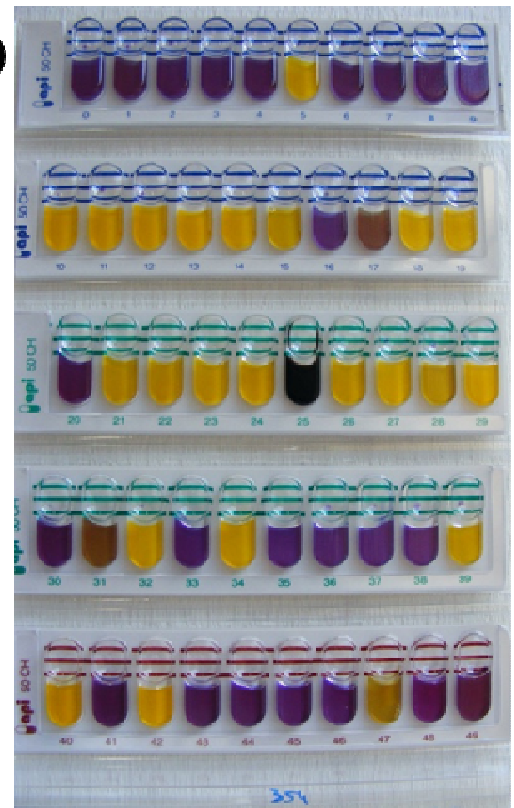

Figure 1. Identification of LAB isolates using a) API 20 Strep identification panels, inoculated with the isolates AKS320.1 and AKS424, and b) API 50 CH identification panel, inoculated with the isolate AKS354. c) API ZYM systems inoculated with the isolates AKS354 and AKS222.2 (see Materials and Methods section). 


\section{Technological properties}

\section{Acidification activity}

Lactic acid bacteria are used as starter culture for the manufacture of fermented dairy products and some cheeses. Lactic acid production from milk sugar lactose is the main function of the dairy starter cultures. LAB play also an important role in the development of flavour and texture of dairy products (KARAKAS-SEN; AKYOL, 2012). Furthermore, LAB produce several antimicrobial substances, which make these bacteria valuable for food biopreservation. These features arouse interest the search of new strains with technological potential (TULINI et al., 2016).

Regarding to the ability to reduce the $\mathrm{pH}$ of $10 \%$ reconstituted skim milk after $24 \mathrm{~h}$, the majority of Lactobacillus isolates were good acid producers than Lactococcus and Enterococcus isolates (Table 2; Table 3). Most of Lactobacillus isolates acidified milk with $\mathrm{pH}$ value below 4.00. Strain $L b$. delbrueckii ssp. lactis AKS369 displayed the highest acidifying activity in milk with $\mathrm{pH} 3.67$ (Table 3). Figure 2a shows the growth of some isolates in $10 \%$ reconstituted skim milk. Acidification ability in skim milk among the cocci was ranged between $\mathrm{pH} 4.33$ and 5.31 (Table 2). In this respect, Lactobacillus isolates could be
KARAKAS-SEN, A.; KARAKAS, E.

considered high acidifiers, as reported elsewhere (MONTEAGUDO-MERA et al., 2011).

\section{Proteolytic activity and starch hydrolysis}

The proteolytic system of LAB is crucial for the optimal growth in milk via the release of proteolytic enzymes. LAB possess a complex system of proteases and peptidases, which allow them to use milk protein casein as a source of amino acids and nitrogen (MAYO et al., 2010). Our results revealed that Lactobacillus isolates tested generally displayed proteolytic activity giving opaque zone on milk agar plates, while few Lactobacillus isolates (Table 3) showed clear zone on milk agar plate (Figure 2b). These results are agreement with the previous results reported by TULINI et al. (2016) which the strains were isolated from milks and cheese.

Starch hydrolysis was tested using starch agar plate. None of the strain displayed activity under that assay conditions. However, among Lactobacillus strains, only one Lb. paracasei ssp. paracasei AKS310.1 strain fermented starch when API $50 \mathrm{CH}$ system was used. One possible explanation for the absence of amylase activity of the tested strain on starch agar plate is maybe due to the fact that the amylase activity is very low to be detected on agar plate compared to API kits. a)

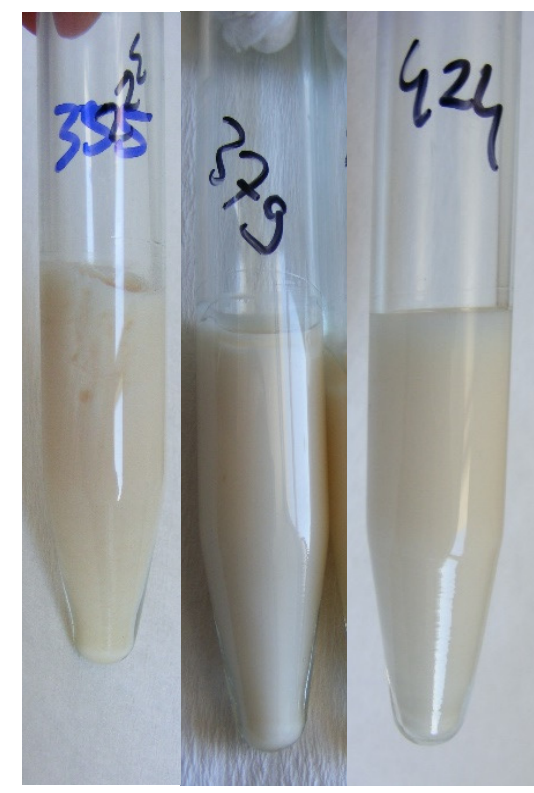

b)

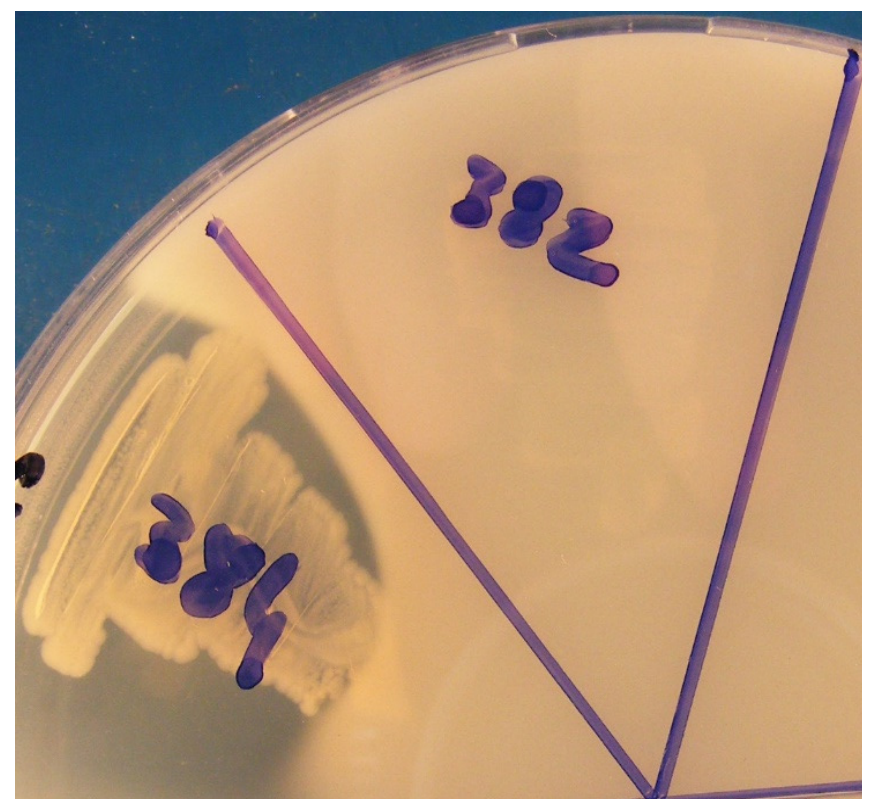

Figure 2. Some technological properties of LAB isolates: a) Growth of the isolates AKS355, AKS379 and AKS424 in reconstituted skim milk, b) Growth of the isolates AKS382 and AKS384 on milk agar. 
Table 2. Some technological characteristics of the coccoid shape wild lactic acid bacteria isolated from raw cow milk

\begin{tabular}{|c|c|c|c|c|c|}
\hline \multirow{2}{*}{ Strain code } & \multirow{2}{*}{$\begin{array}{l}\text { Species } \\
\text { Identification by API } 20 \text { Strep }\end{array}$} & \multirow[b]{2}{*}{$\begin{array}{l}\text { Growth in } \\
\text { Milk }^{\mathbf{a}}(\mathbf{p H})\end{array}$} & \multicolumn{3}{|c|}{ Antimicrobial activity against } \\
\hline & & & $\begin{array}{l}\text { S. aureus } \\
\text { ATCC } 25923\end{array}$ & $\begin{array}{l}\text { C. perfringens } \\
\text { ATCC } 13124\end{array}$ & $\begin{array}{l}\text { L. monocytogenes } \\
\text { ATCC } 7644\end{array}$ \\
\hline AKS203.1 & Enterococcus durans & 4.71 & + & - & - \\
\hline AKS207.1 & Enterococcus faecium & 4.72 & + & - & - \\
\hline AKS208.1 & Enterococcus durans & 4.71 & - & + & - \\
\hline AKS216.1 & Enterococcus durans & 4.83 & - & - & - \\
\hline AKS236.2 & Lactococcus lactis ssp. lactis & 4.35 & - & - & - \\
\hline AKS240.2 & Enterococcus faecium & 4.74 & - & + & - \\
\hline AKS271.1 & Enterococcus durans & 4.81 & - & - & - \\
\hline AKS273.1 & Enterococcus durans & 4.73 & - & - & - \\
\hline AKS301.1 & Streptococcus salivarius & 4.62 & - & + & - \\
\hline AKS302.1 & Lactococcus lactis ssp. lactis & 4.73 & - & + & + \\
\hline AKS303.3 & Lactococcus lactis ssp. lactis & 4.50 & - & - & + \\
\hline AKS304.1 & Lactococcus lactis ssp. lactis & 4.49 & - & - & - \\
\hline AKS307.1 & Lactococcus lactis ssp. lactis & 4.80 & - & - & - \\
\hline AKS312.1 & Lactococcus lactis ssp. lactis & 4.54 & - & - & + \\
\hline AKS313.1 & Enterococcus faecalis & 5.31 & - & - & - \\
\hline AKS316.2 & Lactococcus lactis ssp. lactis & 4.48 & - & - & + \\
\hline AKS317.2 & Lactococcus lactis ssp. lactis & 4.74 & - & - & - \\
\hline AKS318.1 & Lactococcus lactis ssp. lactis & 4.52 & - & - & - \\
\hline AKS320.1 & Lactococcus lactis ssp. lactis & 4.74 & + & + & + \\
\hline AKS320.2 & Lactococcus lactis ssp. lactis & 4.77 & + & + & + \\
\hline AKS323.2 & Lactococcus lactis ssp. lactis & 4.63 & - & - & + \\
\hline AKS331.2 & Lactococcus lactis ssp. lactis & 4.53 & - & + & - \\
\hline AKS336.2 & Lactococcus lactis ssp. lactis & 4.94 & - & - & - \\
\hline AKS342.1 & Lactococcus lactis ssp. lactis & 4.44 & - & + & - \\
\hline AKS349.2 & Lactococcus lactis ssp. lactis & 4.56 & - & - & - \\
\hline AKS350 & Enterococcus faecium & 4.33 & - & + & - \\
\hline AKS360 & Lactococcus lactis ssp. lactis & 4.35 & - & - & - \\
\hline AKS365 & Enterococcus avium & 3.72 & - & + & - \\
\hline AKS402 & Lactococcus lactis ssp. lactis & 5.20 & - & - & + \\
\hline AKS406 & Lactococcus lactis ssp. lactis & 4.33 & - & - & + \\
\hline AKS409 & Lactococcus lactis ssp. lactis & 4.41 & - & - & - \\
\hline AKS410 & Lactococcus lactis ssp. lactis & 4.37 & - & - & - \\
\hline AKS411 & Lactococcus lactis ssp. lactis & 4.80 & - & - & - \\
\hline AKS413 & Lactococcus lactis ssp. lactis & 4.50 & - & - & + \\
\hline AKS418 & Lactococcus lactis ssp. lactis & 5.02 & - & - & + \\
\hline AKS419 & Enterococcus faecalis & 5.01 & - & + & - \\
\hline AKS420 & Lactococcus lactis ssp. lactis & 5.04 & - & - & + \\
\hline AKS422 & Lactococcus lactis ssp. lactis & 4.51 & + & - & - \\
\hline AKS423 & Lactococcus lactis ssp. lactis & 4.34 & - & - & - \\
\hline AKS424 & Enterococcus faecalis & 4.92 & - & + & + \\
\hline AKS425 & Lactococcus lactis ssp. lactis & 4.37 & - & - & - \\
\hline AKS426 & Lactococcus lactis ssp. lactis & 4.59 & - & - & - \\
\hline
\end{tabular}

+, positive; -, negative. All of LAB strains were cocci, gram positive, catalase negative, oxidase negative. ${ }^{\mathrm{a}}$ Growth in sterile reconstituted skim milk. 
Table 3. Some technological characteristics of the rod shape wild lactic acid bacteria isolated from raw cow milk

\begin{tabular}{|c|c|c|c|c|c|c|c|c|}
\hline \multirow[b]{2}{*}{$\begin{array}{l}\text { Strain } \\
\text { code }\end{array}$} & \multirow[b]{2}{*}{ Genus } & \multirow{2}{*}{$\begin{array}{l}\text { Species } \\
\text { Identification by API } 50 \mathrm{CH}\end{array}$} & \multirow[b]{2}{*}{ 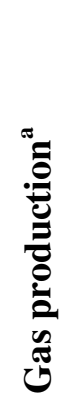 } & \multirow[b]{2}{*}{ 尊 } & \multirow[b]{2}{*}{ 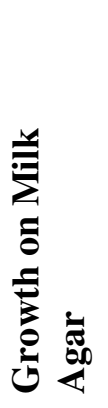 } & \multicolumn{3}{|c|}{$\begin{array}{l}\text { Antimicrobial } \\
\text { activity against }\end{array}$} \\
\hline & & & & & & 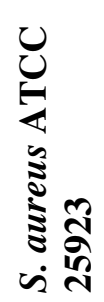 & 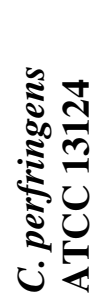 & 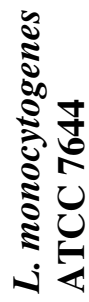 \\
\hline AKS209.1 & Lactobacillus & & + & 5.79 & $+^{\mathrm{c}}$ & - & - & - \\
\hline $\mathrm{AKS} 210.2$ & Lactobacillus & & - & 3.76 & ND & - & - & - \\
\hline AKS212.2 & Lactobacillus & & - & 3.81 & $+^{c}$ & - & + & - \\
\hline AKS213.1 & Lactobacillus & & + & 5.34 & $t^{\mathrm{c}}$ & - & + & - \\
\hline AKS215.2 & Lactobacillus & & - & 3.80 & ND & - & + & - \\
\hline AKS222.2 & Lactobacillus & Lb. fermentum & + & 4.94 & $t^{c}$ & + & + & + \\
\hline AKS255.1 & Lactobacillus & & - & 4.73 & ND & + & - & - \\
\hline AKS310.1 & Lactobacillus & Lb. paracasei ssp. paracasei & - & 5.06 & $+^{c}$ & - & + & + \\
\hline AKS351 & Lactobacillus & & - & 3.74 & $+^{\mathrm{c}}$ & - & - & - \\
\hline AKS352 & Lactobacillus & Lb. delbrueckii ssp. lactis & - & 5.33 & $+^{\mathrm{o}}$ & - & - & - \\
\hline AKS353 & Lactobacillus & & - & 4.36 & $+^{\mathrm{o}}$ & - & + & - \\
\hline AKS354 & Lactobacillus & Lb. rhamnosus & - & 3.98 & $+^{\mathrm{o}}$ & + & + & + \\
\hline AKS355 & Lactobacillus & & - & 4.19 & $+^{\circ}$ & - & - & - \\
\hline AKS356 & Lactobacillus & & - & 6.03 & $+^{\mathrm{c}}$ & + & + & - \\
\hline AKS357 & Lactobacillus & & - & 4.85 & - & + & - & - \\
\hline AKS358 & Lactobacillus & Lb. rhamnosus & - & 3.69 & $+^{\mathrm{o}}$ & - & - & - \\
\hline AKS359 & Lactobacillus & & - & 5.97 & $+^{\circ}$ & - & - & - \\
\hline AKS361 & Lactobacillus & & - & 3.67 & $+^{\mathrm{o}}$ & - & - & - \\
\hline AKS362 & Lactobacillus & & - & 5.59 & - & - & - & - \\
\hline AKS363 & Lactobacillus & & - & 3.83 & $+^{\mathrm{o}}$ & + & - & - \\
\hline AKS364 & Lactobacillus & Lb. acidophilus & - & 3.81 & $+^{\mathrm{c}}$ & - & - & - \\
\hline AKS367 & Lactobacillus & Lb. paracasei ssp. paracasei & - & 4.57 & $+^{\mathrm{o}}$ & + & + & - \\
\hline AKS369 & Lactobacillus & Lb. delbrueckii ssp. lactis & - & 3.67 & $+^{\mathrm{c}}$ & + & + & + \\
\hline AKS370 & Lactobacillus & & - & 3.76 & $+^{c}$ & - & - & - \\
\hline AKS371 & Lactobacillus & & - & 3.75 & $+^{\mathrm{c}}$ & + & - & - \\
\hline AKS372 & Lactobacillus & Lb. delbrueckii ssp. lactis & - & 3.74 & $+^{\mathrm{c}}$ & - & - & - \\
\hline AKS379 & Lactobacillus & & - & 3.74 & $+^{c}$ & - & - & + \\
\hline AKS382 & Lactobacillus & Lb. plantarum & - & 3.90 & - & + & + & + \\
\hline AKS384 & Lactobacillus & & - & 4.80 & $+^{\mathrm{c}}$ & - & + & - \\
\hline AKS385 & Lactobacillus & & - & 4.40 & ND & - & - & - \\
\hline AKS386 & Lactobacillus & Lb. paracasei $\mathrm{ssp}$. paracasei & - & 3.80 & $t^{\circ}$ & + & + & + \\
\hline AKS387 & Lactobacillus & Lb. paracasei ssp. paracasei & - & 3.74 & $t^{\circ}$ & + & + & + \\
\hline AKS389 & Lactobacillus & Lb. plantarum & - & 4.10 & $t^{\mathrm{c}}$ & + & + & + \\
\hline AKS400 & Lactobacillus & Lb. paracasei ssp. paracasei & - & 3.74 & $+^{\circ}$ & + & + & + \\
\hline
\end{tabular}

+ , positive; - , negative. All of LAB isolates were rod shape, gram-positive, catalase negative, oxidase negative and non-spore containing. ${ }^{\mathrm{a}}$ Gas production assay was conducted in MRS broth with inverted Durham tubes at $37^{\circ} \mathrm{C}$ for 2 days. ${ }^{\mathrm{b}}$ Growth in sterile reconstituted skim milk; $+^{\circ}$ opaque zone on milk agar; $+^{c}$ clear zone on milk agar. ND, Not Determined. 


\section{Antimicrobial activity of the LAB isolates}

LAB produce some antimicrobial substances (lactic acid, diacetyl, bacteriocins etc.) active against spoilage and pathogen microorganisms (DEEGAN et al., 2006; KARAKAS-SEN; AKYOL, 2012). Our results revealed that most of $\mathrm{LAB}$ isolates showed antimicrobial activity against at least one of the food
KARAKAS-SEN, A.; KARAKAS, E.

pathogens tested (Table 2; Table 3; Table 4). The highest percentage $(32.22 \%)$ of the isolates displayed an inhibitory activity against $C$. perfringens ATCC 13124. This was followed by the antimicrobial activity against $L$. monocytogenes ATCC 7644 and S. aureus ATCC 25923 with $26.67 \%$ and $23.33 \%$, respectively (Table 4 ).

Table 4. Antimicrobial activity of lactic acid bacteria isolates from raw cow milk

\begin{tabular}{|c|c|c|c|c|c|c|c|}
\hline \multirow{3}{*}{ Isolates } & \multirow{3}{*}{$\begin{array}{l}\text { Number } \\
\text { tested }\end{array}$} & \multicolumn{6}{|c|}{ Antimicrobial activity against } \\
\hline & & \multicolumn{2}{|c|}{$\begin{array}{l}\text { L. monocytogenes } \\
\text { ATCC } 7644\end{array}$} & \multicolumn{2}{|c|}{$\begin{array}{l}\text { S. aureus ATCC } \\
25923\end{array}$} & \multicolumn{2}{|c|}{$\begin{array}{l}\text { C. perfringens ATCC } \\
\mathbf{1 3 1 2 4}\end{array}$} \\
\hline & & No & $\%^{a}$ & No & $\%^{a}$ & No & $\%^{\mathrm{a}}$ \\
\hline \multicolumn{8}{|l|}{ Cocci } \\
\hline Lactococcus & 33 & 12 & 36.36 & 3 & 9.10 & 5 & 15.15 \\
\hline Enterococcus & 18 & 2 & 11.11 & 4 & 22.22 & 7 & 38.89 \\
\hline Streptococcus & 4 & 0 & & 0 & & 1 & 25.00 \\
\hline Leuconostoc & 1 & 0 & & 0 & & 0 & \\
\hline Total & 56 & 14 & 25.00 & 7 & 12.50 & 13 & 23.21 \\
\hline \multicolumn{8}{|l|}{ Rods } \\
\hline Lactobacillus & 34 & 10 & 29.41 & 14 & 41.18 & 16 & 47.06 \\
\hline General Total & 90 & 24 & 26.67 & 21 & 23.33 & 29 & 32.22 \\
\hline
\end{tabular}

${ }^{\text {a }}$ Percentage of total isolates showing antimicrobial activity against indicator strain.

Based on the diameter of halos ( $\mathrm{mm})$ using agar well assays, $3 \mathrm{LAB}$ isolates (Lc. lactis ssp. lactis AKS320.1, AKS320.2, and E. faecalis AKS424) displayed a high antimicrobial activity were further studied (Figure 3a, b). The nature of inhibitory activities was evaluated with $\alpha$-amylase, catalase, lipase and some proteases: proteinase $\mathrm{K}$, pepsin, $\alpha$-chymotrypsin, trypsin and papain. The antibacterial activity of $E$. faecalis AKS424 was completely inactivated by $\alpha$-chymotrypsin, pepsin and proteinase $\mathrm{K}$ (Figure $3 \mathrm{~b}$ ), and partially inactivated by lipase. Heat treatment (for $5 \mathrm{~m}$ at $100^{\circ} \mathrm{C}$ ) slightly reduced the activity. The diameter of zone of inhibition without and with heat treatment was $14.00 \mathrm{~mm}$, and $12.16 \mathrm{~mm}$, respectively. Moreover, the inhibitory activity of the bacteriocin produced by $E$. faecalis AKS424 was evaluated against gram-negative bacteria $E$. coli $\mathrm{EC} 100$ and $E$. coli MC1022. Although this bacteriocin was not active against gram-negative bacteria tested, it was active against $L$ b. bulgaricus 572 , and the isolate Lb. fermentum AKS222.2.

Bacteriocins are antimicrobial peptides and sensitive to proteolytic enzymes. Our results revealed that the antibacterial activities of two $L c$. lactis ssp. lactis AKS320.1, AKS320.2 and E. faecalis AKS424 strains were completely inactivated by proteinase $K$. Therefore, the proteinaeous nature of the antimicrobial substances produced by these three isolates was established their sensitivity to proteolytic enzyme protease K. Similar results have been recorded for bacteriocins produced by E. faecalis and Lc. lactis (PERIN; NERO, 2014; ASPRI et al., 2017). Our results revealed that amongst the tested LAB, Lc. lactis ssp. lactis AKS320.1 and AKS320.2 and E. faecalis AKS424 demonstrated a good potential for the application as starter or probiotic culture in human and veterinary feeds.

The author EDEN (2014) reported that $E$. faecium and E. faecalis strains have been prepared as commercial probiotic supplements by SymbioPharm, Germany and Cerbios Pharma SA, Switzerland, respectively. In addition, E. faecalis Symbioflor I had been consumed by humans as a probiotic strain without adverse effects for more than 50 years. The results from another study (MORENO et al., 2006) demonstrated that E. faecium SF68 was effective in the prevention of antibiotic-associated diarrhea, and was patented as probiotic. Recently, a new E. faecium strain isolated from raw camel milk exhibited important probiotic characteristics such as high cholesterol removal percentages, capability to inhibit pathogens, reasonable acid and bile tolerance, and sensitivity to antibiotics with no haemolysis (AYYASH et al., 
2018). Regarding to the ability of bacteriocin production, LAB may constitute an ecological advantage to be predominant in raw milk (RODRIGUEZ et al., 2000). a)

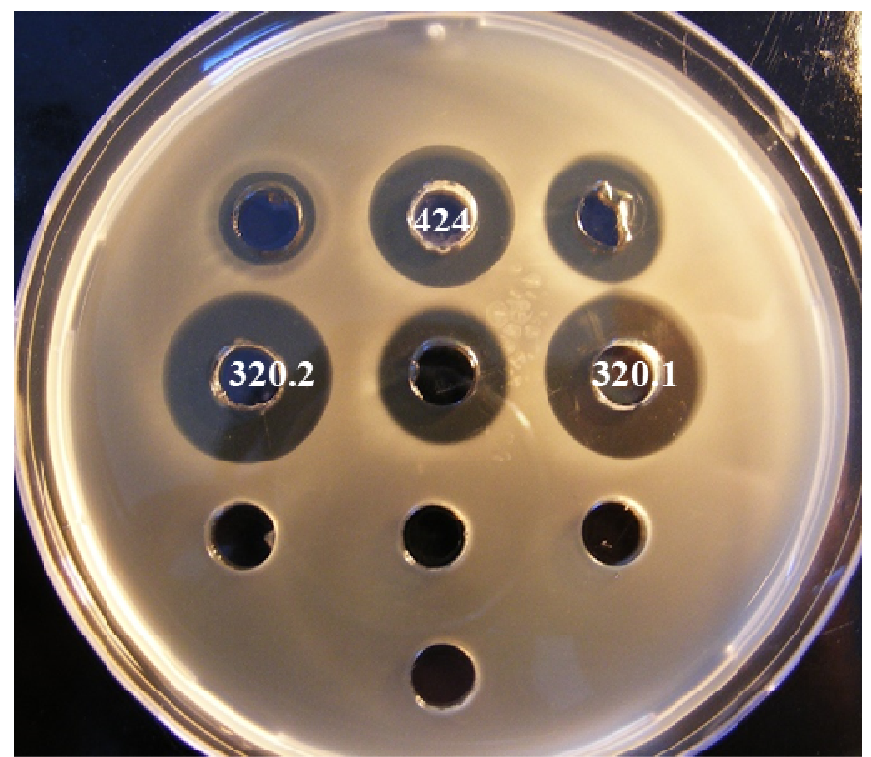

b)

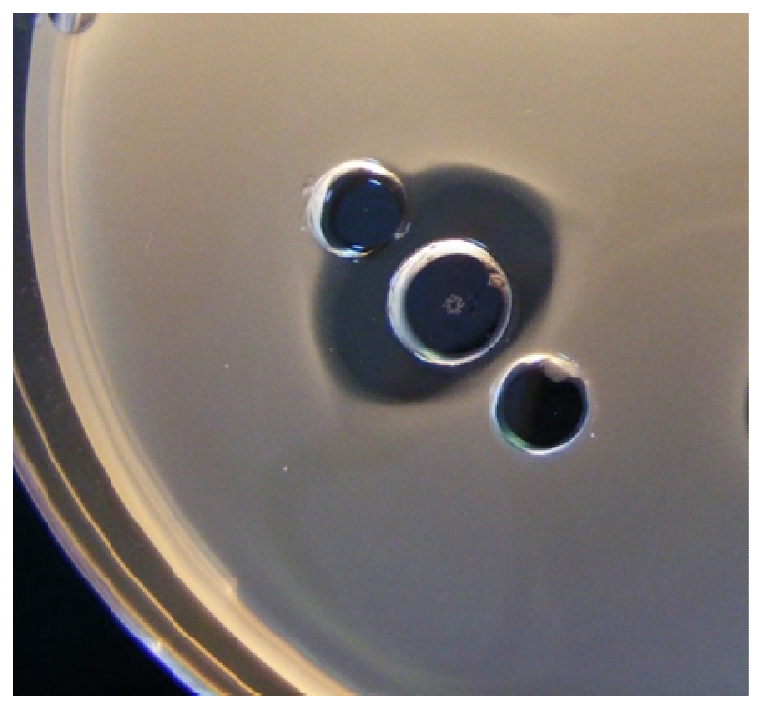

Figure 3. The cell free supernatant activity of LAB isolates as monitored by agar well-diffusion assay using $L$. monocytogenes ATCC 7644 as the indicator strain. a) The supernatants of Lc. lactis ssp. lactis AKS320.1, AKS320.2, and E. faecalis AKS424 were marked as 320.1, 320.2, and 424, respectively. b) Effect of the protease enzyme proteinase $\mathrm{K}$ on the antibacterial activity of the cell free supernatant of E. faecalis AKS424.

\section{Enzyme activity}

To compare the biochemical properties of the isolated strains, the enzyme activities of the selected 17 strains (8 cocci, 9 Lactobacillus spp.) were tested using API ZYM system (Figure 1c). The results showed that the strains tested were positive for 18 of 19 enzymes activities (Table 5). No activity was detected for the enzyme $\alpha$ mannosidase. Our results revealed that the enzyme activities have varied among the strains and between the same strains. All strains tested showed leucine arylamidase, acid phosphatase, and naphthol-AS-BIphosphohydrolase activities. Amongst the 17 LAB strains tested, Lactobacillus spp. strains displayed a high leucine arylamidase activity. These findings are in agreement with results reported by other authors for Lactobacillus spp. isolated from raw milks (MONTEAGUDO-MERA et al., 2011). The enzyme leucine arylamidase (EC 3.4.11.2) catalyses the removal of an $\mathrm{N}$-terminal leucine from arylamides or p-nitroanilides (MÜLLER et al., 2004). Regard to the development of desirable flavours, aminopeptidase enzyme activity is an important technological characterisation for the strains of LAB planned for use as starter for the production of cheese (MONTEAGUDO-MERA et al., 2011).
The enzyme activities for $\alpha$-galactosidase, $\beta$-galactosidase, $\beta$-glucuronidase, and $\beta$-glucosidase were only detected for the strains of Lactobacillus genus. Amongst Enterococcus spp. and Lactococcus spp. strains tested, none of them displayed $\beta$ glucuronidase activity, while 4 isolates (AKS222.2, AKS212.2, AKS354 and AKS369) of 9 Lactobacillus spp. displayed very low $\beta$ glucuronidase activity. The authors (GILL; ROWLAND, 2002) reported that $\beta$-glucuronidase enzyme has been associated with the stimulation of colon cancer by converting precarcinogens into proximal carcinogens. Therefore, the lack of $\beta$ glucuronidase enzyme activity is an asset for the potential use of these strains as dairy starter cultures.

$\beta$-Galactosidase activity was found at the highest values in the strains of Lactobacillus spp., but it was absent in the other strains tested (Table 5). Our results revealed that amongst LAB tested, the strains $L b$. plantarum AKS382 and $L b$. plantarum AKS389 displayed N-Acetyl- $\beta$ glucosaminidase enzyme activity. These results are agreement with the results reported by PULIDO et al. (2007) for some $L b$. plantarum strains isolated from caper berry fermentations. 
Table 5. Enzyme activities of the selected lactic acid bacteria strains isolated from raw cow milk determined using the API-ZYM system (bioMérieux, France) Enzyme tested $^{\mathrm{a}}$

Strain

\begin{tabular}{|c|c|c|c|c|c|c|c|c|c|c|c|c|c|c|c|c|c|}
\hline \multicolumn{18}{|c|}{ Enzyme tested $^{\mathrm{a}}$} \\
\hline 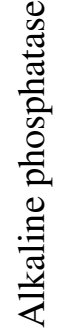 & 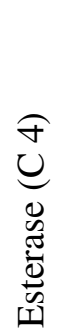 & 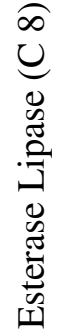 & 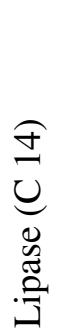 & 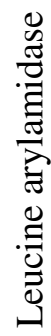 & 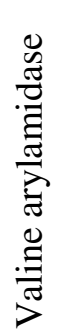 & 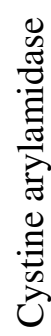 & 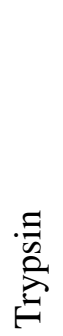 & 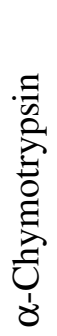 & 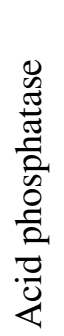 & 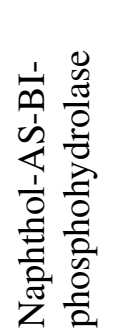 & 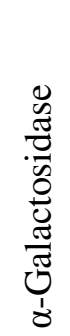 & 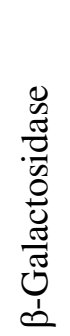 & 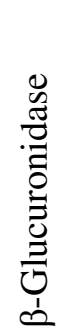 & 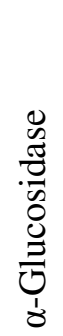 & 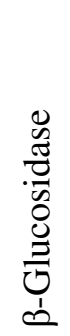 & 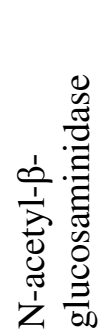 & 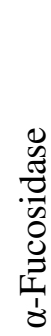 \\
\hline
\end{tabular}

\section{Cocci}

Enterococcus durans AKS273.1

Lactococcus lactis ssp. lactis AKS320.2

Lactococcus lactis ssp. lactis AKS323.2

Lactococcus lactis ssp. lactis AKS331.2

Lactococcus lactis ssp. lactis AKS349.2

Enterococcus faecium AKS350

Enterococcus faecalis AKS419

Enterococcus faecalis AKS424

Rods

Lactobacillus fermentum AKS222.2

Lactobacillus rhamnosus AKS354

Lactobacillus acidophilus AKS364

Lactobacillus paracasei ssp. paracasei

AKS367

Lactobacillus delbrueckii ssp. lactis

AKS369

Lactobacillus delbrueckii ssp. lactis

AKS372

Lactobacillus plantarum AKS382

Lactobacillus plantarum AKS389

Lactobacillus AKS212.2

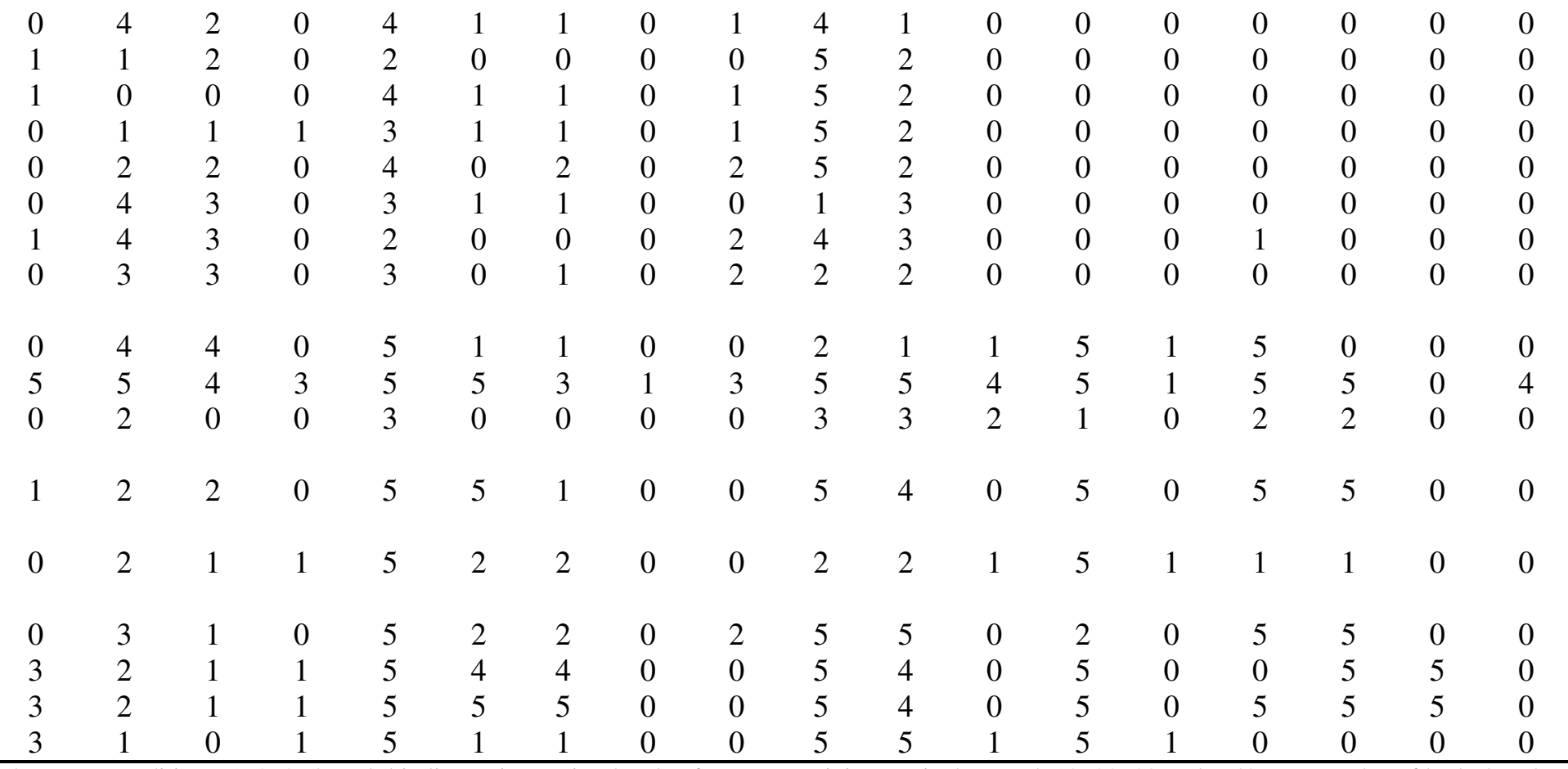

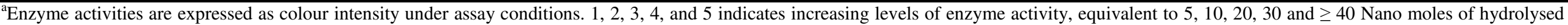

substrate after $4 \mathrm{~h}$ incubation at $37^{\circ} \mathrm{C} ; 0$, no activity detected. No activity was detected for the enzyme $\alpha$-mannosidase. 
L-Fucosidases (EC 3.2.1.51), which are exoglycosidases capable of cleaving-linked Lfucose residues from fucosyloligosaccharides, play the important roles in the adaptation of bacteria to the particular niches (BECKER; LOWE, 2003). Lfucose (6-deoxy-L-galactose) is a monosaccharide that occurs at the nonreducing end of many glycans on mammalian cell surfaces, intestinal mucin, blood group antigens, and human milk oligosaccharides (HMO). The analysis of API ZYM results revealed that only Lb. rhamnosus AKS354 strain showed $\alpha$ L-fucosidase enzyme activity. Our results are agreement with the previous study (BECERRA et al., 2015) reported the characterisation of L-fucose operon a probiotic strain $L b$. rhamnosus GG. In another study, Lb. rhamnosus ATCC 53103 strain showed $\alpha$-fucosidase enzyme activity that helps the colonization in the intestine (MONTEAGUDOMERA et al., 2011). Only one strain Lb. rhamnosus AKS354 displayed trypsin activity at very low level (Table 5). The lack or low levels of trypsin enzyme activity is a positive aspect for strains which are intended to be used as starter or probiotic cultures (MONTEAGUDO-MERA et al., 2011). The strain Lb. rhamnosus AKS354 showing high $\alpha$-fucosidase and low trypsin enzyme activities may be a good candidate for probiotic strain.

\section{CONCLUSIONS}

The diversity of LAB in the raw cow milk indigenous microbiota exhibits a good source of new bacterial strains with interesting technological properties.

Bacteriocin producing strains could be good candidates for the application of milk fermentations, bio-preservation or probiotic organism.

\section{ACKNOWLEDEGEMENTS}

This work was supported by The Commission of Scientific Research Projects of Uludag University (Project No: UAP(YIOMYO)2012/25).

\begin{abstract}
RESUMO: Bactérias de ácido lático são utilizadas como cultura inicial para a produção de produtos lácteos fermentados e que ocorrem naturalmente como microbiota indígena do leite cru. Neste estudo, as bactérias ácido lácticas foram isoladas a partir de amostras de leite cru de vaca. As diluições em série do leite cru foram feitos e plaqueadas em ágar LM17 e agar MRS ajustado para pH 5,4. Os isolados foram primeiramente identificados com base na morfologia das células, coloração pelo Método de Gram, produção de catalase, crescimento em caldo MRS contendo 2\%, 4\%, e 6,5\% de $\mathrm{NaCl}$, a capacidade de crescimento de diferentes temperaturas e formação de gás em caldo MRS. Foram avaliadas a formação de ácido em $10 \%$ de leite desnatado reconstituído e propriedades antagonistas contra os agentes patogênicos de origem alimentar Listeria monocytogenes ATCC 7644, Stapylococcus aureus ATCC 25923, e Clostridium perfringens ATCC 13124, usando o método de difusão em agar. O total de 90 isolados de laboratório foram classificados como Lactobacillus (37,78\%), de Lactococcus (36,67\%), Enterococcus (20,00\%), Streptococcus (4,44\%), e Leuconostoc $(1,11 \%)$. Com base em propriedades tecnológicas, foram selecionados 56 dos 90 isolados (42 cocos, 14 hastes) e identificados ao nível das espécies usando o sistema de identificação API 20 Strep e API 50 CH, respectivamente. Os isolados de Lactobacillus foram identificados como Lactobacillus acidophilus, Lactobacillus fermentum, Lactobacillus paracasei ssp. paracasei, Lactobacillus plantarum, Lactobacillus delbrueckii ssp. lactis e Lactobacillus rhamnosus. Os perfis enzimáticos dos 17 isolados selecionados foram estudados por meio do sistema API ZYM. As cepas de Lactobacillus possuem alta atividade de arilamidase leucina. Duas cepas de Lactococcus lactis ssp. lactis AKS320,1 e AKS320,2 cepas e um Enterococcus faecalis AKS424 estirpe foram capazes de produzir bacteriocina. Em conclusão, alguns destes isolados poderiam ser considerados como potenciais candidatos de cultura iniciadora para produtos à base de leite fermentados.
\end{abstract}

PALAVRAS-CHAVE: Bactérias do ácido láctico. Bacteriocina. Isolamento. Identificação. Leite cru de vaca.

\title{
REFERENCES
}

ALEMAYEHU, D.; HANNON, J. A.; MCAULIFFE, O.; ROSS, R. P. Characterization of plant-derived lactococci on the basis of their volatile compounds profile when grown in milk. International Journal of Food Microbiology, v. 172, p. 57-61, 2014. https://doi.org/10.1016/j.ijfoodmicro.2013.11.024

ASPRI, M.; BOZOUDI, D.; TSALTAS, D.; HILL, C.; PAPADEMAS, P. Raw donkey milk as a source of Enterococcus diversity: Assessment of their technological properties and safety characteristics. Food Control, v. 73, p. 81-90, 2017. https://doi.org/10.1016/j.foodcont.2016.05.022 
AYAD, E. H. E.; VERHEUL, A.; JONG, C. DE; WOUTERS, J. T. M.; SMIT, G. Flavour forming abilities and amino acid requirements of Lactococcus lactis strains isolated from artisanal and non-dairy origin.

International Dairy Journal, v. 9, n. 10, p. 725-735, 1999. https://doi.org/10.1016/S0958-6946(99)00140-5

AYYASH, M.; ABUSHELAIBI, A.; AL-MAHADIN, S.; ENAN, M.; EL-TARABILY, K.; SHAH, N. In-vitro investigation into probiotic characterisation of Streptococcus and Enterococcus isolated from camel milk. LWT - Food Science and Technology, v. 87, p. 478-487, 2018. https://doi.org/10.1016/j.lwt.2017.09.019

BECERRA, J. E.; YEBRA, M. J.; MONEDERO, V. An L-fucose operon in the probiotic Lactobacillus rhamnosus GG is involved in adaptation to gastrointestinal conditions. Applied and Environmental Microbiology, v. 81, n. 11, p. 3880-3888, 2015. https://doi.org/10.1128/AEM.00260-15

BECKER, D. J.; LOWE, J. B. Fucose: Biosynthesis and biological function in mammals. Glycobiology, v. 13, n. 7, p. 41R-53R, 2003. https://doi.org/10.1093/glycob/cwg054

CHEN, Y.; LIAO, Y.; LAN, Y.; WU, H.; YANAGIDA, F. Diversity of lactic acid bacteria associated with banana fruits in Taiwan. Current Microbiology, v. 74, n. 4, p. 484-490, 2017. https://doi.org/10.1007/s00284017-1213-2

COGAN, T. M.; BARBOSA, M.; BEUVIER, E.; BIANCHI-SALVADORI, B.; COCCONCELLI, P.S.; FERNANDES, I.; GOMEZ, J.; GOMEZ, R.; KALANTZOPOULOS, G.; LEDDA, A.; MEDINA, M.; REA, M.C.; RODRIGUEZ, E. Characterization of the lactic acid bacteria in artisanal dairy products. Journal of Dairy Research, v. 64, p. 409-21, 1997. https://doi.org/10.1017/S0022029997002185

CORROLER, D.; MANGIN, I.; DESMASURES, N.; GUEGUEN, M. An ecological study of lactococci isolated from raw milk in the camembert cheese registered designation of origin area. Applied and Environmental Microbiology, v. 64, n. 12, p. 4729-4735, 1998.

DEEGAN, L. H.; COTTER, P. D.; HILL, C.; ROSS, P. Bacteriocins: Biological tools for bio-preservation and shelf-life extension. International Dairy Journal, v. 16, n. 9, p. 1058-1071, 2006.

https://doi.org/10.1016/j.idairyj.2005.10.026

DELAVENNE, E.; MOUNIER, J.; DÉNIEL, F.; BARBIER, G.; BLAY, G. LE. Biodiversity of antifungal lactic acid bacteria isolated from raw milk samples from cow, ewe and goat over one-year period.

International Journal of Food Microbiology, v. 155, n. 3, p. 185-190, 2012.

https://doi.org/10.1016/j.ijfoodmicro.2012.02.003

DOUILLARD, F. P.; VOS, W. M. DE. Functional genomics of lactic acid bacteria: From food to health. Microbial Cell Factories, v. 13, n. Suppl 1, p. S8, 2014.

DUNCAN, S. E.; YAUN, B. R.; SUMNER, S. S.; BRUHN, J. Chapter 09 Microbiological methods for dairy products. In: WEHR, H. M.; FRANK, J. F. (Eds.). Standard Methods for the Examination of Dairy Products. 17th Edition. American Public Health Association, 2004. p. 249-268.

https://doi.org/10.2105/9780875530024ch09

EDEN, R. Enterobacteriaceae, Coliforms and E. coli I Classical and modern methods for detection and enumeration. In: BATT, C. A.; TORTORELLO, M. LOU (Eds.). . Encyclopedia of Food Microbiology Second Edition ed. Oxford: Academic Press, 2014. p. 667-673.

EGAN, A. F. Lactic acid bacteria of meat and meat products. Antonie van Leeuwenhoek, v. 49, n. 3, p. 327336, 1983. https://doi.org/10.1007/BF00399507

FRANCIOSI, E.; SETTANNI, L.; CAVAZZA, A.; POZNANSKI, E. Biodiversity and technological potential of wild lactic acid bacteria from raw cows' milk. International Dairy Journal, v. 19, n. 1, p. 3-11, 2009. https://doi.org/10.1016/j.idairyj.2008.07.008 
GILL, C. I. R.; ROWLAND, I. R. Diet and cancer: assessing the risk. British Journal of Nutrition, v. 88, n. S1, p. s73, 2002. https://doi.org/10.1079/BJN2002632

HARRIGAN, W. F. Laboratory Methods in Food Microbiology. Academic Press, 1998.

HORVATH, P.; COÛTÉ-MONVOISIN, A. C.; ROMERO, D. A.; BOYAVAL, P.; FREMAUX, C.; BARRANGOU, R. Comparative analysis of CRISPR loci in lactic acid bacteria genomes. International Journal of Food Microbiology, v. 131, n. 15th Meeting of the Club des Bacteries Lactiques, p. 62-70, 2009. https://doi.org/10.1016/j.ijfoodmicro.2008.05.030

KARAKAS-SEN, A.; NARBAD, A.; HORN, N.; DODD, H. M.; PARR, A. J.; COLQUHOUN, I.; GASSON, M. J. Post-translational modification of nisin. The involvement of NisB in the dehydration process. European Journal of Biochemistry, v. 261, n. 2, p. 524-532, 1999. https://doi.org/10.1046/j.1432-1327.1999.00303.x

KARAKAS-SEN, A.; AKYOL, I. Expression of dar gene in lactic acid bacteria and effect on metabolite formation in feta-type cheese quality. Food Biotechnology, v. 26, n. 1, p. 45-57, 2012. https://doi.org/10.1080/08905436.2011.645938

KELLY, W. J.; DAVEY, G. P.; WARD, L. J. H. Characterization of lactococci isolated from minimally processed fresh fruit and vegetables. International Journal Of Food Microbiology, v. 45, n. 2, p. 85-92, 1998. https://doi.org/10.1016/S0168-1605(98)00135-4

LAW, B. A.; KOLSTAD, J. Proteolytic systems in lactic acid bacteria. Antonie van Leeuwenhoek, v. 49, n. 3, p. 225-245, set. 1983. https://doi.org/10.1007/BF00399500

MAYO, B.; ALEKSANDRZAK-PIEKARCZYK, T.; FERNÁNDEZ, M.; KOWALCZYK, M.; ÁLVAREZMARTÍN, P.; BARDOWSKI, J. Updates in the Metabolism of Lactic Acid Bacteria. In: Biotechnology of Lactic Acid Bacteria: Novel Applications, Blackwell Publishing p. 3-33, 2010. https://doi.org/10.1002/9780813820866.ch1

MONTEAGUDO-MERA, A.; CARO, I.; RODRÍGUEZ-APARICIO, L. B.; RÚA, J.; FERRERO, M. A.; GARCÍA-ARMESTO, M. R. Characterization of certain bacterial strains for potential use as starter or probiotic cultures in dairy products. Journal of Food Protection, v. 74, n. 8, p. 1379-1386, 2011.

https://doi.org/10.4315/0362-028X.JFP-10-392

MORENO, M. R. F.; SARANTINOPOULOS, P.; TSAKALIDOU, E.; VUYST, L. DE. The role and application of enterococci in food and health. International Journal of Food Microbiology, v. 106, n. 1, p. 124, 2006. https://doi.org/10.1016/j.ijfoodmicro.2005.06.026

MÜLLER, T.; MÜLLER, M.; BEHRENDT, U. Leucine arylamidase activity in the phyllosphere and the litter layer of a Scots pine forest. FEMS Microbiology Ecology, v. 47, n. 2, p. 153-159, 2004.

https://doi.org/10.1016/S0168-6496(03)00258-7

NOMURA, M.; KOBAYASHI, M.; NARITA, T.; KIMOTO-NIRA, H.; OKAMOTO, T. Phenotypic and molecular characterization of Lactococcus lactis from milk and plants. Journal of Applied Microbiology, v. 101, n. 2, p. 396-405, 2006. https://doi.org/10.1111/j.1365-2672.2006.02949.x

OLASUPO, N. A.; SCHILLINGER, U.; NARBAD, A.; DODD, H.; HOLZAPFEL, W. H. Occurrence of nisin $\mathrm{Z}$ production in Lactococcus lactis BFE 1500 isolated from wara, a traditional Nigerian cheese product. International Journal of Food Microbiology, v. 53, n. 2-3, p. 141-152, 1999. https://doi.org/10.1016/S01681605(99)00146-4

PERIN, L. M.; BELVISO, S.; BELLO, B. DAL; NERO, L. A.; COCOLIN, L. Technological properties and biogenic amines production by bacteriocinogenic Lactococci and Enterococci strains isolated from raw goat's milk. Journal of Food Protection, v. 80, n. 1, p. 151, jan. 2017. https://doi.org/10.4315/0362-028X.JFP-16267 
PERIN, L. M.; NERO, L. A. Antagonistic lactic acid bacteria isolated from goat milk and identification of a novel nisin variant Lactococcus lactis. BMC Microbiology, v. 14, n. 1, p. 1-9, 2014.

https://doi.org/10.1186/1471-2180-14-36

PERRY, K. D.; SHARPE, M. E. Lactobacilli in raw milk and in Cheddar cheese. Journal of Dairy Research, v. 27, n. 2, p. 267-275, 1960. https://doi.org/10.1017/S0022029900010335

PULIDO, R. P.; OMAR, N. BEN; ABRIOUEL, H.; LÓPEZ, R. L.; CAÑAMERO, M. M.; GUYOT, J. P.; GÁLVEZ, A. Characterization of lactobacilli isolated from caper berry fermentations. Journal of Applied Microbiology, v. 102, n. 2, p. 583-590, 2007. https://doi.org/10.1111/j.1365-2672.2006.03067.x

QUIGLEY, L.; O'SULLIVAN, O.; STANTON, C.; BERESFORD, T. P.; ROSS, R. P.; FITZGERALD, G. F.; COTTER, P. D. The complex microbiota of raw milk. FEMS Microbiology Reviews, v. 37, n. 5, p. 664-698, 2013. https://doi.org/10.1111/1574-6976.12030

RODRÍGUEZ, E.; GONZÁLEZ, B.; GAYA, P.; NUÑEZ, M.; MEDINA, M. Diversity of bacteriocins produced by lactic acid bacteria isolated from raw milk. International Dairy Journal, v. 10, n. 1-2, p. 7-15, 2000. https://doi.org/10.1016/S0958-6946(00)00017-0

RYAN, M. P.; REA, M. C.; HILL, C.; ROSS, R. P. An application in cheddar cheese manufacture for a strain of Lactococcus lactis producing a novel broad-spectrum bacteriocin, lacticin 3147. Applied and

Environmental Microbiology, v. 62, n. 2, p. 612-619, 1996.

SCHAEFFER, A. B.; FULTON, M. D. A simplified method of staining endospores. Science, v. 77, n. 1990, p. 194, 1933.

TULINI, F. L.; HYMERY, N.; HAERTLÉ, T.; BLAY, G. LE; MARTINIS, E. C. P. DE. Screening for antimicrobial and proteolytic activities of lactic acid bacteria isolated from cow, buffalo and goat milk and cheeses marketed in the southeast region of Brazil. The Journal of Dairy Research, v. 83, n. 1, p. 115-124, 2016. https://doi.org/10.1017/S0022029915000606

WILLIAMS, A. G.; BANKS, J. M. Proteolytic and other hydrolytic enzyme activities in non-starter lactic acid bacteria (NSLAB) isolated from cheddar cheese manufactured in the United Kingdom. International Dairy Journal, v. 7, n. 12, p. 763-774, 1997. https://doi.org/10.1016/S0958-6946(97)00092-7

WOUTERS, J. T. M.; AYAD, E. H. E.; HUGENHOLTZ, J.; SMIT, G. Microbes from raw milk for fermented dairy products. International Dairy Journal, v. 12, n. 2-3, SI, p. 91-109, 2002. 